rate of $81 \%$ from arterial surgery in renal artery stenosis, Chamberlain and Gleeson (1965) pointed out that of all cases submitted to diagnostic arteriography only $4 \%$ received eventual surgical benefit, whereas $22 \%$ suffered significant morbidity, and they doubted the benefit of undertaking the original arteriogram. In our group of seven cases with positive angiograms only two were cured surgically and one other had the complication of popliteal occlusion.

\section{Conclusion}

Our experience with a small series of patients with coeliac axis compression has not been as sanguine as that of the previously larger series, but we feel it is important to report this in order to sound a note of caution lest patients become indiscriminately exposed to hazards, both operative and angiographic, in the expectation of the cure of their chronic abdominal pain. We feel that the validity of the syndrome and the efficacy of its treatment need further assessment before either can be unreservedly accepted into routine clinical practice.

We wish to thank the Board of Governors of St. Bartholomew's Hospital for financial support.

\section{REFERENCES}

Birkett, D. A., Apthorp, G. H., Chamberlain, D. A., Hayward, G. W., and Tuckwell, E. G. (1965). British Medical fournal, 2, 187.
Burnett, C. F., and Evans, J. A. (1956). fournal of the American Medical Association, 162, 709

Chamberlain, M. J., and Gleeson, J. A. (1965). Lancet, 1, 619.

DeBakey, M. E., Morris, G. C., Morgen, R. O., Crawford, E. S., and Cooley, D. A. (1964). American Fournal of Surgery, 107, 84

Deutsch, V. (1968). Clinical Radiology, 19, 309.

Dick, A. P., Graff, R., Gregg, D. McC., Peters, N., and Sarner, M. (1967). Gut, 8, 206.

Drapanas, T., and Bron, K. M. (1966). Annals of Surgery, 164, 1085

Dunbar, J. D., Molnar, W., Beman, F. F., and Marable, S. A.' (1965). American fournal of Roentgenology, Radium Therapy, and Nuclear Medicine, 95, 731 .

Edwards, A. J. (1969). Proceedings of the Royal Society of Medicine, $62,488$.

Harjola, P. T. (1963). Annales Chirurgiae et Gynaecologiae Fenniae, 52,

Harjola, P. T., and Lahtihariu, A. (1968). American fournal of Surgery, $115,864$.

Julius, S., and Stewart, B. H. (1967). New England fournal of Medicine, 276, 1175

Lindgren, I. (1950). Acta Medica Scandinavica, Suppl. No. 243.

Lord, R. S. A., Stoney, R. J., and Wylie, E. J. (1968). Lancet, 2, 795.

Marable, S. A., Kaplan, M. F., and Beman, F. M. (1968). American Fournal of Surgery, 115, 97

Marable, S. A., Molnar, W., and Beman, F. M. (1966). American fournal of Surgery, 111, 493 .

Meaney, T. F., and Kistner, R. L. (1967). Archives of Surgery, 94, 811 .

Michels, N. A. (1955). Blood Supply and Anatomy of the Upper Abdominal Organs. Philadelphia, Lippincott.

Palumbo, L. T., and Lulu, D. J., (1963). Surgery, 53, 563.

Reuter, S. R., and Olin, T. (1965). Radiology, 85, 617.

Rob, C. (1967). American fournal of Surgery, 114, 363.

Sedlacek, R. A., and Bean, W. B. (1957). Annals of Internal Medicine, 46, 148 .

Snyder, M. A., Mahoney, E. B., and Rob, C. G. (1967). Surgery, 61, 372 .

Sutton, R. A. L. (1967). Proceedings of the Royal Society of Medicine, $60,139$.

White, J. C., and Bland, E. F. (1948). Medicine, 27, 1.

\title{
Defibrination Syndrome due to Scorpion Venom Poisoning
}

\section{SITA DEVI, ${ }^{*}$ M.B., B.S., M.SC. ; C. NARASIMHARA REDDY, $\dagger$ M.B., в.s. ; S. LAKSHMI DEVI, $\dagger$ M.B., в.s., D.c.P.; Y. R. SUBRAHMANYAM, $\ddagger$ H. VENKATAKRISHNA BHATT, $\$ M.sc. ; G. SUVARNAKUMARI, $\|$ M.B., B.s. ; D. PRASANTHA MURTHY, M.B., B.S. ; C. R. R. M. REDDY,** M.D.}

\begin{abstract}
Summary: Disseminated intravascular coagulation $\checkmark$. occurred in dogs given scorpion venom subcutaneously in doses of $3 \mathrm{mg}$. $/ \mathrm{kg}$. body weight. Treatment with heparin reversed the coagulation abnormality of the syndrome and 10 out of 12 dogs survived. Necropsy findings in human patients stung by scorpions suggest that this syndrome also occurs in man.
\end{abstract}

\section{Introduction}

This study was prompted by the finding that the sting of the scorpion often proved fatal in children and adults within 24 to 48 hours. Necropsy examinations carried out on four children and three adults who died of scorpion venom poisoning showed congestion in all the organs. Subendocardial haemorrhages were present in two, mural thrombosis of the heart in one, and massive haemorrhage of the adrenals in one and of the frontal lobe in another. There were pinpoint haemorrhages in the cerebral cortex. Histological examination

\footnotetext{
* Professor of Biochemistry.

+ Tutor in Biochemistry.

$\ddagger$ Demonstrator, Department of Biochemistry.

Assistant Research Officer, Department of Pharmacology.

Tutor in Pathology.

II Assistant Research Officer, Department of Pathology.

** Professor of Pathology.

Kurnool Medical College, Kurnool, S. India.
}

showed occlusions of small blood vessels with thrombi in the heart, lungs, brain, kidneys, and adrenals, which indicated disseminated intravascular coagulation resulting in defibrination and consequent haemorrhages.

\section{Materials and Methods}

The venom used was from a scorpion of the species Buthus tamulus, which is very common in Kurnool, a part of Rayalaseema from which this study is reported. Venom was extracted from the telson by means of a six-volt electric shock (Deoras, 1960). Drops of venom issuing from the sting were collected in a previously weighed glass test-tube. The contents of the tube were diluted with a known volume of distilled water. Fresh venom was used throughout the study. Clotting-time (Lee and White, 1913), prothrombin time (Quick, 1935), serial thrombin time (Brodsky et al., 1968), euglobulin lysis time (Cash, 1966), platelet count (Dameshek, 1932), and fibrinogen levels (Devi and Naganna, 1969) were estimated.

Preliminary experiments carried out on six dogs showed that the venom in doses of $0.75 \mathrm{mg} . / \mathrm{kg}$. injected subcutaneously had no effect at all, doses of $2.5 \mathrm{mg}$. $/ \mathrm{kg}$. had some effect, but doses of $3 \mathrm{mg} . / \mathrm{kg}$. had the maximum effect and invariably killed the dogs in two to four hours. Similarly, 25$\mathrm{mg}$. doses of heparin given intramuscularly to four dogs in a 
preliminary experiment showed that the clotting-time of the blood was doubled in one hour. The level of heparin in the blood was maintained at two to three times the control level by repeated injections every four hours.

The effects of subcutaneous injections of $3 \mathrm{mg} . / \mathrm{kg}$. of venom were then noted on the first group of 12 dogs. A similar injection of venom preceded by $25 \mathrm{mg}$. of heparin intramuscularly was given to the second group of 12 dogs and the effects were noted. The second group was given a further dose of heparin every four hours for 24 hours, this was then tailed off over the next 12 hours. Wherever excessive salivation and vomiting were present dexamethasone $2 \mathrm{mg}$. intramuscularly was given after injection of venom.

\section{Results}

Of the 12 dogs given venom alone 10 died. All these had clinically excessive salivation, initial restlessness, dilated pupils, tachycardia, rapid respiration, and frequent urination and defaecation. All the dogs became very quiet half to one
Coagulation studies performed two hours after the injection of venom showed a prolonged serial thrombin time, hypofibrinogenaemia, thrombocytopenia, and a normal or slightly raised euglobulin lysis time compared with the control values before the injection of venom. In only one case was there a decrease in euglobulin lysis time (Table I). Prothrombin time was increased in all cases, the values being 52, 70, 56, 40, 80, and $75^{\prime \prime}$, of preinjection values in the six dogs.

Necropsy studies on these six dogs showed subendocardial haemorrhages in five, haemorrhages into kidney and lung in four, and haemorrhagic necrosis of intestines in four: congestion of all the organs was found in the six. On histological examination there were thrombi occluding the capillaries and haemorrhages in the heart, kidney, and lungs in five cases, the intestines in four, the spleen, liver, and adrenals in three, the pancreas in two, and the brain in one.

Of the 12 dogs given heparin and venom 10 survived. Clinically excessive salivation was present in 10 of the 12 dogs, which could be controlled by dexamethasone. All the dogs were less restless, but frequent urination and defaecation

TABLE I.-Effect of Scorpion Venom on Coagulation studies

\begin{tabular}{|c|c|c|c|c|c|c|c|c|c|c|c|}
\hline \multirow{2}{*}{$\begin{array}{l}\text { Dog } \\
\text { No. }\end{array}$} & \multirow{2}{*}{$\begin{array}{l}\text { Hours after } \\
\text { Injection }\end{array}$} & \multicolumn{6}{|c|}{ Serial Thrombin Time in Seconds at Incubation of } & \multirow[b]{2}{*}{$60 \mathrm{~min}}$. & \multirow[b]{2}{*}{$\begin{array}{l}\text { Fibrinogen } \\
\text { (mg. } 100 \mathrm{ml} . \mathrm{s}\end{array}$} & \multirow[b]{2}{*}{$\begin{array}{l}\text { Platelets } \\
1.10^{3} \\
\text { cu. } \mathrm{mm} \text { ) }\end{array}$} & \multirow[b]{2}{*}{$\begin{array}{l}\text { E.L.T.* } \\
\text { minutes }\end{array}$} \\
\hline & & $0 \mathrm{~min}$. & $10 \mathrm{~min}$ & $20 \mathrm{~min}$ & $30 \mathrm{~min}$. & $40 \mathrm{~min}$ & $50 \mathrm{~min}$. & & & & \\
\hline 1 & $\begin{array}{l}0 \\
2\end{array}$ & $\begin{array}{l}5 \cdot 0 \\
8 \cdot 0\end{array}$ & $\begin{array}{r}6 \cdot 0 \\
12 \cdot 0\end{array}$ & $\begin{array}{r}8 \cdot 0 \\
28 \cdot 0\end{array}$ & $\begin{array}{l}10.5 \\
31.5\end{array}$ & $\begin{array}{l}16 \cdot 0 \\
35.5\end{array}$ & $\begin{array}{r}16 \cdot 0 \\
48 \cdot 0\end{array}$ & $\begin{array}{l}20 \cdot 0 \\
67 \cdot 0\end{array}$ & $\begin{array}{l}318 \\
164\end{array}$ & $\begin{array}{r}121 \\
59\end{array}$ & $\begin{array}{l}160 \\
176\end{array}$ \\
\hline 2 & $\begin{array}{l}0 \\
2\end{array}$ & $\begin{array}{r}3.5 \\
10.5\end{array}$ & $\begin{array}{r}4 \cdot 0 \\
15 \cdot 0\end{array}$ & $\begin{array}{r}45 \\
22 \cdot 0\end{array}$ & $\begin{array}{r}6 \cdot 0 \\
48 \cdot 5\end{array}$ & $\begin{array}{r}8 \cdot 0 \\
63 \cdot 0\end{array}$ & $\begin{array}{l}12 \cdot 0 \\
84.5\end{array}$ & $\begin{array}{r}18 \cdot 0 \\
108 \cdot 0\end{array}$ & $\begin{array}{l}400 \\
120\end{array}$ & $\begin{array}{l}288 \\
128\end{array}$ & $\begin{array}{l}148 \\
156\end{array}$ \\
\hline 3 & $\begin{array}{l}0 \\
2\end{array}$ & $\begin{array}{r}6 \cdot 0 \\
12 \cdot 0\end{array}$ & $\begin{array}{r}8 \cdot 0 \\
14.5\end{array}$ & $\begin{array}{l}10 \cdot 5 \\
25 \cdot 0\end{array}$ & $\begin{array}{l}13.5 \\
50.5\end{array}$ & $\begin{array}{l}15 \cdot 0 \\
70 \cdot 5\end{array}$ & $\begin{array}{l}20 \cdot 0 \\
85 \cdot 0\end{array}$ & $\begin{array}{r}22 \cdot 0 \\
110 \cdot 5\end{array}$ & $\begin{array}{l}265 \\
188\end{array}$ & $\begin{array}{r}148 \\
79\end{array}$ & $\begin{array}{l}210 \\
125\end{array}$ \\
\hline 4 & $\begin{array}{l}0 \\
2\end{array}$ & $\begin{array}{l}3 \cdot 0 \\
5 \cdot 5\end{array}$ & $\begin{array}{l}5 \cdot 0 \\
9 \cdot 0\end{array}$ & $\begin{array}{r}7.5 \\
10.5\end{array}$ & $\begin{array}{r}8.5 \\
11.5\end{array}$ & $\begin{array}{l}10 \cdot 5 \\
15 \cdot 5\end{array}$ & $\begin{array}{l}12 \cdot 5 \\
27 \cdot 5\end{array}$ & $\begin{array}{l}15 \cdot 0 \\
42 \cdot 0\end{array}$ & $\begin{array}{l}380 \\
114\end{array}$ & $\begin{array}{r}119 \\
79\end{array}$ & $\begin{array}{l}125 \\
130\end{array}$ \\
\hline 5 & $\begin{array}{l}0 \\
2\end{array}$ & $\begin{array}{l}3.5 \\
5.5\end{array}$ & $\begin{array}{l}4 \cdot 5 \\
6 \cdot 5\end{array}$ & $\begin{array}{l}4 \cdot 5 \\
9 \cdot 5\end{array}$ & $\begin{array}{r}5 \cdot 0 \\
11 \cdot 0\end{array}$ & $\begin{array}{r}6 \cdot 5 \\
16 \cdot 0\end{array}$ & $\begin{array}{r}8 \cdot 0 \\
42 \cdot 5\end{array}$ & $\begin{array}{l}13.5 \\
61.5\end{array}$ & $\begin{array}{l}379 \\
146\end{array}$ & $\begin{array}{l}318 \\
141\end{array}$ & $\begin{array}{l}170 \\
180\end{array}$ \\
\hline 6 & $\begin{array}{l}0 \\
2\end{array}$ & $\begin{array}{l}3.5 \\
6.5\end{array}$ & $\begin{array}{l}5 \cdot 0 \\
6.5\end{array}$ & $\begin{array}{r}8 \cdot 5 \\
10 \cdot 0\end{array}$ & $\begin{array}{l}12 \cdot 5 \\
18 \cdot 5\end{array}$ & $\begin{array}{l}16 \cdot 5 \\
30 \cdot 5\end{array}$ & $\begin{array}{l}22 \cdot 0 \\
55 \cdot 0\end{array}$ & $\begin{array}{r}25 \cdot 5 \\
110 \cdot 0\end{array}$ & $\begin{array}{l}418 \\
212\end{array}$ & $\begin{array}{l}261 \\
141\end{array}$ & $\begin{array}{l}178 \\
184\end{array}$ \\
\hline
\end{tabular}

*Euglobulin lysis time.

hour after the injection. Disturbances in heart rate and rhythm occurred in 10 of the dogs, distension in eight, and grossly bloody motions in four. Though necropsy examinations were carried out on all of the dogs that died, the results are confined to six in which complete coagulation studies were done. occurred in only two, of which one died. Coagulation studies showed that there was no fall in fibrinogen levels or platelet counts in the dogs treated with heparin, nor were the results of thrombin clotting-time affected to any great extent (Table II). This fact may have been due to sampling of blood four hours after injection of heparin.

TABLE II.-Effect of Therapy on Coagulation studies

\begin{tabular}{|c|c|c|c|c|c|c|c|c|c|c|c|c|}
\hline \multirow{2}{*}{$\begin{array}{l}\text { Dog } \\
\text { No. }\end{array}$} & \multirow{2}{*}{$\begin{array}{c}\text { Hours } \\
\text { of } \\
\text { therapy }\end{array}$} & \multicolumn{7}{|c|}{ Serial Thrombin Time in Seconds at Incubation of } & \multirow{2}{*}{$\begin{array}{l}\text { Fibrinogen } \\
\text { (mg./100ml.) }\end{array}$} & \multirow[b]{2}{*}{$\begin{array}{c}\text { Platelet } \\
\text { count } \\
\times 10^{3} / \text { cu.mm. }\end{array}$} & \multirow{2}{*}{ E.L.T. } & \multirow{2}{*}{ Therapy } \\
\hline & & $0 \mathrm{~min}$. & $10 \mathrm{~min}$. & $20 \mathrm{~min}$. & $30 \mathrm{~min}$. & $40 \mathrm{~min}$. & $50 \mathrm{~min}$. & $60 \mathrm{~min}$. & & & & \\
\hline A & $\begin{array}{r}0 \\
4 \\
24\end{array}$ & $\begin{array}{l}5 \\
5 \\
-\end{array}$ & $\begin{array}{r}10.5 \\
12.0 \\
\end{array}$ & $\begin{array}{l}13 \\
14.5\end{array}$ & $\begin{array}{l}15.0 \\
16.5\end{array}$ & $\begin{array}{l}16.5 \\
17 \cdot 0\end{array}$ & $\begin{array}{l}20 \cdot 0 \\
23 \cdot 0 \\
-\end{array}$ & $\begin{array}{l}22 \cdot 0 \\
25 \cdot 0\end{array}$ & $\begin{array}{l}422 \\
418 \\
432\end{array}$ & $\begin{array}{l}150 \\
141 \\
155\end{array}$ & $\begin{array}{l}155 \\
210 \\
160\end{array}$ & $\begin{array}{l}\text { Heparin } \\
\text { and } \\
\text { cortisone }\end{array}$ \\
\hline B & $\begin{array}{r}0 \\
4 \\
24\end{array}$ & $\begin{array}{l}5 \\
6.5 \\
-\end{array}$ & $\begin{array}{r}6 \cdot 0 \\
12 \cdot 0\end{array}$ & $\begin{array}{r}8.5 \\
19 \cdot 0 \\
-\end{array}$ & $\begin{array}{l}10.5 \\
19.0 \\
-\end{array}$ & $\begin{array}{l}11 \cdot 0 \\
20 \cdot 0 \\
-\end{array}$ & $\begin{array}{l}13 \cdot 0 \\
25 \cdot 0 \\
-\end{array}$ & $\begin{array}{l}15.5 \\
30.0\end{array}$ & $\begin{array}{l}318 \\
298 \\
324\end{array}$ & $\begin{array}{r}102 \\
98 \\
106\end{array}$ & $\begin{array}{l}125 \\
120 \\
116\end{array}$ & Heparin \\
\hline C & $\begin{array}{r}0 \\
4 \\
24\end{array}$ & $\begin{array}{r}3 \cdot 0 \\
3 \cdot 5 \\
\end{array}$ & $\begin{array}{l}4 \cdot 0 \\
4 \cdot 0 \\
-\end{array}$ & $\begin{array}{l}6.5 \\
7.5 \\
-\end{array}$ & $\begin{array}{l}8 \cdot 5 \\
8 \cdot 5 \\
-\end{array}$ & $\begin{array}{l}10.0 \\
11.5\end{array}$ & $\begin{array}{l}12 \cdot 0 \\
13 \cdot 0\end{array}$ & $\begin{array}{l}18.5 \\
22.5 \\
-\end{array}$ & $\begin{array}{l}511 \\
540 \\
524\end{array}$ & $\begin{array}{l}82 \\
82 \\
83\end{array}$ & $\begin{array}{l}125 \\
115 \\
130\end{array}$ & $\begin{array}{l}\text { Heparin } \\
\text { and } \\
\text { cortisone }\end{array}$ \\
\hline D & $\begin{array}{r}0 \\
4 \\
24\end{array}$ & $\begin{array}{l}7 \cdot 0 \\
7 \cdot 0 \\
-\end{array}$ & $\begin{array}{l}8 \cdot 5 \\
8 \cdot 0\end{array}$ & $\begin{array}{l}12.5 \\
13 \cdot 0\end{array}$ & $\begin{array}{l}14.0 \\
16.5\end{array}$ & $\begin{array}{l}16 \cdot 0 \\
18 \cdot 5\end{array}$ & $\begin{array}{l}20 \cdot 5 \\
21 \cdot 0\end{array}$ & $\begin{array}{l}22 \cdot 0 \\
25.0\end{array}$ & $\begin{array}{l}438 \\
432 \\
416\end{array}$ & $\begin{array}{l}72 \\
71 \\
78\end{array}$ & $\begin{array}{l}115 \\
130 \\
125\end{array}$ & $\begin{array}{l}\text { Heparin } \\
\text { and } \\
\text { cortisone }\end{array}$ \\
\hline E & $\begin{array}{r}0 \\
4 \\
24\end{array}$ & $\begin{array}{r}3.5 \\
4.5 \\
\end{array}$ & $\begin{array}{l}6 \cdot 5 \\
7 \cdot 5 \\
-\end{array}$ & $\begin{array}{l}8 \cdot 0 \\
8 \cdot 5 \\
-\end{array}$ & $\begin{array}{r}9 \cdot 5 \\
12 \cdot 5 \\
-\end{array}$ & $\begin{array}{l}16.5 \\
16.0 \\
-\end{array}$ & $\begin{array}{l}22.5 \\
23 \cdot 5 \\
-\end{array}$ & $\begin{array}{l}28 \cdot 0 \\
30 \cdot 0 \\
-\end{array}$ & $\begin{array}{l}398 \\
378 \\
380\end{array}$ & $\begin{array}{l}109 \\
108 \\
110\end{array}$ & $\begin{array}{l}176 \\
186 \\
168\end{array}$ & Heparin \\
\hline F & $\begin{array}{r}0 \\
4 \\
24\end{array}$ & $\begin{array}{l}3.5 \\
4.0 \\
\end{array}$ & $\begin{array}{l}4.5 \\
5 \cdot 0 \\
-\end{array}$ & $\begin{array}{l}6.0 \\
7.5 \\
\end{array}$ & $\begin{array}{l}8 \cdot 5 \\
9 \cdot 0 \\
-\end{array}$ & $\begin{array}{l}12 \cdot 0 \\
14.0\end{array}$ & $\begin{array}{r}16 \cdot 5 \\
21 \cdot 0 \\
\end{array}$ & $\begin{array}{l}23.5 \\
38.5 \\
-\end{array}$ & $\begin{array}{l}266 \\
232 \\
284\end{array}$ & $\begin{array}{l}121 \\
120 \\
124\end{array}$ & $\begin{array}{l}168 \\
174 \\
180\end{array}$ & $\begin{array}{l}\text { Heparin } \\
\text { and } \\
\text { cortisone }\end{array}$ \\
\hline
\end{tabular}
The data against zero hours of therapy indicate the baseline control values before injection of the venom or heparin and that against four hours indicate the values four hours
after heparin and three hours after venom injections. 


\section{Discussion}

Disseminated intravascular coagulation or defibrination syndrome is known to be concerned in the pathogenesis of various diseases (Hardaway and McKay, 1963). Heparin therapy is often effective in controlling the bleeding diathesis associated with this disorder (Bernstock and Hirson, 1960; Merskey et al., 1967; Brodsky et al., 1968). It is important, however, to distinguish between the syndromes of disseminated intravascular coagulation and primary fibrinolysis, since the treatment is different. In our study four tests were important in making the diagnosis: platelet count; serial thrombin time; euglobulin lysis time; and plasma fibrinogen levels, which can be used to distinguish between fibrinolysis and tefibrination (Brodsky et al., 1968). On the basis of these tests 'ze coagulation studies carried out on the dogs given scorpion -enom showed that the defibrination syndrome had occurred Table I). Necropsy and histological examination confirmed ' his supposition.

The abnormal coagulation profile was reversed with heparin therapy and the dogs survived (Table II). The bites of some snakes cause intravascular coagulation (Best and Taylor, 1961) similar to that occurring after intravascular injection of thrombin (Hardaway et al., 1960); however, such a syndrome due to a scorpion sting has not yet been described. Myocarditis (Poon-King, 1963), neurotoxicity (Brown, 1959; Manson-Bahr, 1961), and acute pancreatitis (Poon-King, 1963) have been stated to be the cause of death in patients poisoned with scorpion venom.

In cases of defibrination syndrome adequate doses of heparin by continuous intravenous drip produced dramatic effects
(Brodsky et al., 1968). Since it is difficult to give heparin by continuous intravenous drip to a conscious dog, and since given intramuscularly it takes about an hour to double the coagulation time, heparin was administered to the dogs one hour before injection of the venom. The aim of this study was mainly to determine whether heparin in adequate doses could prevent the defibrination syndrome occurring as a result of injections of scorpion venom. Similar coagulation studies need to be carried out in man, and the effect of giving heparin after venom injection in animals must be noted before the effect of heparin in similar cases in man is studied.

\section{REFERENCES}

Bernstock, L., and Hirson, C. (1960). Lancet, 1, 28.

Best, C. H., and Taylor, N. B. (1961). In The Physiological Basis of Medical Practice, 7th ed., p. 115. Baltimore, Williams and Wilkins. Brodsky, I., Meyer, A. N., Kahn, S. B., and Ross, E. M. (1968). American fournal of Clinical Pathology, 50, 211.

Fournal of Clinical Pathology, 50,
Brown, H. W. (1959). In Text Book of Medicine, 10th ed., edited by R. L. Cecil, and R. F. Loeb, p. 414. Philadelphia, Saunders.

Cash, J. D. (1966). British Medical fournal, 2, 502.

Dameshek, W. (1932). Archives of Internal Medicine, 50, 579

Deoras, P. J. (1960). Fournal of the University of Bombay, 29, 179.

Devi, C. S., and Naganna, B. (1969). American fournal of Obstetrics and Gynecology, 103,73.

Hardaway, R. M., and McKay, D. C. (1963). Review of Surgery, 20, 297.

Hardaway, R. M., Watson, H. E., and Weiss, F. H. (1960). Archives of Surgery, 81, 983.

Lee, R. I., and White, P. D. (1913). American fournal of Medical Sciences, 145, 495 .

Manson Bahr, P. H. (editor) (1961). In Tropical Diseases, 15th ed., p. 881. London, Cassell.

Merskey, C., Johnson, A. J., Kleiner, G. J., and Wohl, H. (1967). British fournal of Haematology, 13, 528 .

Poon-King, T. (1963). British Medical Journal, 1, 374.

Quick, A. J. (1935). Fournal of Biological Chemistry, 109, 1xxiii.

\section{Medical Memoranda}

\section{Wasting of Napkin Area after Repeated Use of Fluorinated Steroid Ointment}

British Medical fournal, 1970, 1, 347-348

Fluorinated steroid ointments have an extremely wide use in the treatment of napkin dermatitis. The following case illustrates local and probably some general effects of repeated applications. The local effect was atrophy of the skin and subcutaneous tissues in the napkin area, which initially led to diagnostic confusion with coeliac disease. Probable general effects were suppression of the pituitary-adrenal axis and inhibition of growth, as shown by a falling rate of weight gain and finally by an actual fall in weight, which was reversed when the application of ointment was stopped.

\section{CASE REPORT}

A girl of 18 months was referred by her doctor because of failure to thrive. In view of the falling rate of growth and a history of bulky stools, which were sometimes pale, she was admitted to hospital for investigation of possible malabsorption.

She was a first child, weighed $2.95 \mathrm{~kg}$. at birth, and had had two exchange transfusions in the first 48 hours of life for $A B O$ incompatibility. By 6 weeks she had developed a non-specific erythematous rash, affecting the napkin area, scalp, face, nape of neck, and later the elbow and knee flexures. Over the next 14 months this was treated with regular applications of Ultralanum

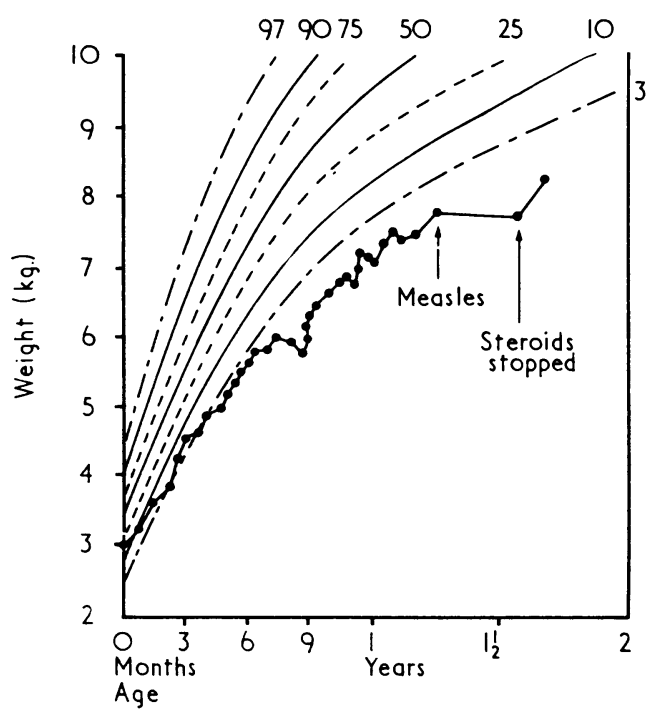

FIG. 1.-Nude weight $v$ age. 